\title{
婦人科がん領域における生活の質向上を目的とした オピオイドスイッチングに関する研究
}

\author{
鈴木 直, 吉田 彩子, 中川 侑子, 波多野美穂, 横道 憲幸, \\ 細沼＼cjkstart信示, 吉岡＼cjkstart範人, 大原＼cjkstart樹, 戸澤＼cjkstart晃子, 木口 一成
}

聖マリアンナ医科大学 産婦人科学

受付日 2011 年 8 月 25 日/改訂日 2012 年 1 月 6 日/受理日 2012 年 4 月 5 日

\begin{abstract}
がん疼痛に対するオピオイド鎮痛薬の開始薬として用いられるオキシコドン徐放性製剂は, その副作用である眠気や便 秘が特に婦人科がん患者にとって生活の質を低下させる要因となりうる. 一方, フェンタニル貼付薬は鎮痛効力が強く, 副 作用が少ないプロファイルを有しているものの, 用法・用量が「オピオイド鎮痛薬から切り替えて使用する」ことになって いる.オキシコドン徐放性製剂の副作用発現例からフェンタニル貼付薬へオピオイドスイッチングした婦人科がん領域の 臨床研究報告は, わが国には存在していない. それ以前の問題として, 婦人科がん領域における緩和医療の早期導入は十分 ではなく，婦人科がん患者にとって満足の得られる段階には達していない現状がある. 本研究では, 婦人科がん患者に特化 した副作用軽減と生活の質向上を目的とした疼痛管理に関する研究を行った結果, 早期にフェンタニル貼付薬へ切り替え ることによって, 婦人科がん患者の疼痛, 眠気, 便秘を有意に改善する結果が得られた。

Palliat Care Res 2012; 7(2): 363-7
\end{abstract}

Key words: 婦人科がん, がん疼痛, フェンタニル貼付薬, オピオイドスイッチング, 眠気

\section{緒 言}

婦人科がんは, 他のがん腫と比べて進行がんの生存率が若干 高い傾向にある. 2007 年 10 月に全国がん (成人病) センター協 議会が公表したデータ ${ }^{1)}$ による $\mathrm{IV}$ 期の 5 年相対生存率は子 宮頸がん：18.0\%, 子宮体がん：23.4\%, 卵巣がん：29.6\%で, 胃 がん: $7.2 \%$, 肺がん: $3.7 \%$ となっている.一方, 婦人科がんの 中で最も予後不良である卵巣がんに対する治療成績は, 1987 年以前のパクリタキセルを含まない治療の 5 年生存率が I 期 : $89.6 \%$ ，II 期 : 74.3\%，III 期 : 29.9\%, IV 期 : 18.1\%であったが, 1988 年以降のパクリタキセルを含む治療では I 期 : $92.6 \%$, II 期 : 70.1\%, III期 : $37.5 \%$, IV 期 : $25.4 \%$ と, III 期と IV 期で改善傾 向を示している21.

以上のように, 婦人科がん領域における手術療法や化学療法 などをあわせた集学的治療の進歩によって, 婦人科がん患者の 生存期間が改善されつつある. しかし, その一方で身体面, 社 会面, 心理面, さらにはホルモン久落による問題など, 多くの点 で女性としての生活の質 (QOL) が損なわれることが多いため, 化学治療と並行して, 患者の病態に合わせた早期の緩和医療の 導入が重要となっている.

疼痛管理においても, 仕事や家事を行っている患者が少なく ないことから, 鎮痛薬を選択寸る際もなるべく副作用が少なく 日常生活活動 $(\mathrm{ADL})$ をさまたげないことが肝要となる. 鎮痛 薬の中心はオピオイド鎮痛薬となるが, フェンタニル貼付薬 (以下, FP) は, モルヒネ徐放性製剤に比べて便秘や眠気の副作
用が少なく ${ }^{3)}$, 婦人科がん患者に対して使用しやすい薬剤とな る可能性が示唆されている. しかし, 婦人科がん領域における 早期の緩和医療導入は満足のいく段階には達しておらず, 婦人 科がん患者に特化した, 副作用軽減を目的とした疼痛管理に関 する研究はほとんど存在していない.

そこで,われわれは疼痛を有する婦人科がん患者を対象に才 キシコドン経口薬 (以下, OC) から副作用発現後早期に FP のオピオイドスイッチングによる, 鎮痛効果および副作用発現 のプロファイルをプロスペクティブに検討した.

\section{方 法}

2008 年 11 月ー 2009 年 12 月まで聖マリアンナ医科大学病院 産婦人科を受診し, 本試験への参加の同意が得られた 10 例の がん疼痛を有する婦人科がん患者を対象とした. 対象症例の背 景を表 1 に記した.

オピオイド製剤投与開始となった, より早期の副作用を検 討する目的で, OC 投与中に嘔気, 嘔吐, 便秘, 日中の眠気の副 作用 $(0-3$ の 4 段階評価で 2 以上) が認められた段階で, FP へ オピオイドスイッチング 9 日間貼付し, 鎮痛効果 (numerical rating scale; NRS: 0-10の 11 段階), 副作用 $(0-3$ の 4 段階評 価), 1 日排便回数, およびレスキュー回数を前向きに検討した. 各症状のスコアは, 患者自身がシートに記入した. なお, 副作用 (0ー3の 4 段階評価) に関しては以下のごとくである. 0: 副作 用はない, 1: 副作用はあってもつらくはない, 2: つらいがなん

\footnotetext{
Corresponding author: 鈴木 直| 聖マリアンナ医科大学 産婦人科学

干 216-88511 神奈川県川崎市宮前区菅生 2-16-1

TEL 044-977-8111 FAX 044-979-5454 E-mail: nao@marianna-u.ac.jp
} 


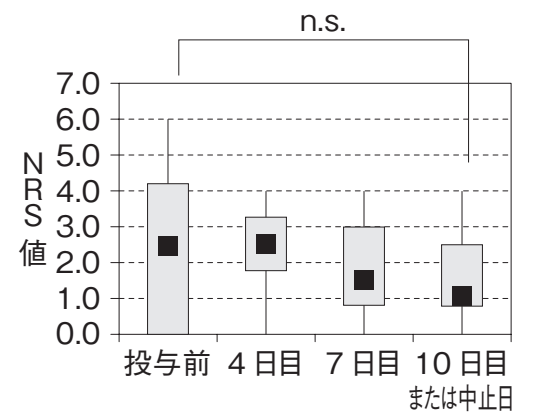

a. 痛み

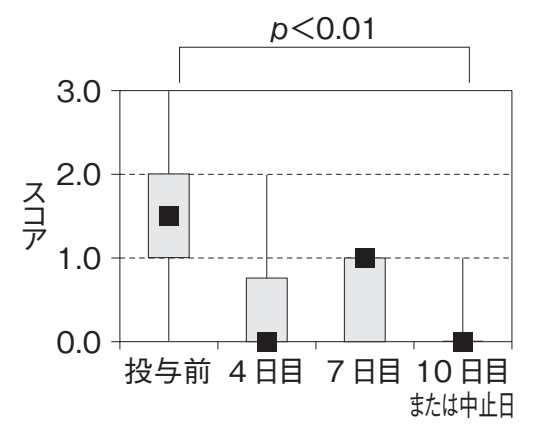

d. 便秘

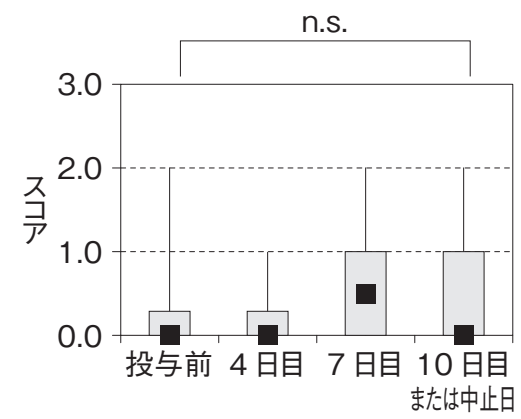

b. 嘔気

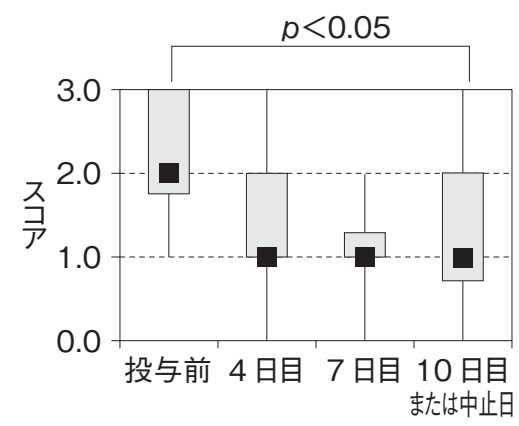

e. 日中の眠気

図 1 本研究における症例の成績

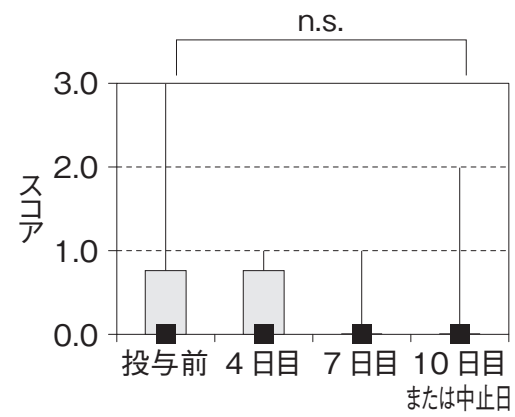

C. 嘔吐

表 1 症例一覧

\begin{tabular}{|c|c|c|c|c|c|c|c|c|}
\hline No & 年齢 & がん腫 & 転移部位 & $\begin{array}{c}\mathrm{OC} \\
\text { 定期投与量 } \\
\text { (mg/日) }\end{array}$ & $\begin{array}{c}\text { OC } \\
\text { 投与期間 } \\
\text { (日) }\end{array}$ & $\begin{array}{c}\mathrm{FP} \\
\text { 開始量 } \\
\text { (mg/3日) }\end{array}$ & $\begin{array}{c}\mathrm{FP} \\
\text { 最終投与量 } \\
(\mathrm{mg} / 3 \text { 日) }\end{array}$ & 併用鎮痛薬 \\
\hline 1 & 55 & 体部 (初発) & $\begin{array}{l}\text { 腹膜播種, 結腸, 小腸, } \\
\text { リンパ節 }\end{array}$ & 10 & 9 & 2.1 & 2.1 & なし \\
\hline 2 & 46 & 卵巣 (再発) & 腹膜播種, 肺, 脾臓 & 10 & 54 & 2.1 & 2.1 & NSAIDs \\
\hline 3 & 37 & 卵巣 (再発) & リンパ節 & 10 & 10 & 2.1 & 2.1 & NSAIDs \\
\hline 4 & 51 & 卵巣 (初発) & 腹膜播種, 肝臓 & 10 & 6 & 2.1 & 2.1 & NSAIDs \\
\hline 5 & 36 & 頸部 (初発) & 仙骨 & 10 & 3 & 2.1 & 2.1 & NSAIDs \\
\hline 6 & 51 & 頸部 (再発) & 肝臓, 骨 & 10 & 14 & 2.1 & 2.1 & NSAIDs \\
\hline 7 & 55 & 体部 (再発) & 腔, リンパ節 & 10 & 8 & 2.1 & 2.1 & NSAIDs \\
\hline 8 & 74 & 体部 (再発) & 膣, 肺 & 10 & 9 & 2.1 & 2.1 & なし \\
\hline 9 & 69 & 体部 (再発) & リンパ節, 骨 & 40 & 12 & 4.2 & 8.4 & NSAIDs \\
\hline 10 & 59 & 頸部 (再発) & 肺 & 10 & 5 & 2.1 & 4.2 & なし \\
\hline
\end{tabular}

とか耐えられる, 3: 耐えられないくらいつらい. また, 鎮痛効 果および副作用のスコアについては, OC 投与期と FP 投与期 の中央值を比較し Wilcoxon の符号付順位和検定により解析を 行った. なお, $\mathrm{OC}$ 投与開始時には, 副作用対策 (副作用の情報 提供ならびに制吐剤, 緩下剂投与) を十分に行った患者を対象 としている。

なお, 本試験実施にあたり聖マリアンナ医科大学生命倫理委 員会の承認を得た (承認番号 1450 号).

\section{成 績}

OCから FPへのオピオイドスイッチング前後の疼痛強度
(NRS 值)の中央值は 2.5 から 1.0 一低下した (有意差なし：図 $1-a$ ). 副作用症状スコアの中央值は, 嘔気 $0.0 \rightarrow 0.0$ (有意差な し: 図 1-b), 嘔吐 $0.0 \rightarrow 0.0$ (有意差なし: 図 1-c), 便秘 $1.5 \rightarrow 0.0$ (有意差あり $: p<0.01$, 図 1-d), 日中の眠気 $2.0 \rightarrow 1.0$ (有意差あ り $: p<0.05$, 図 1-e) であった. 1 日の排便回数は $0.0 \rightarrow 1.0,1$ 日 のレスキュー回数は $0.0 \rightarrow 0.0$ であった. なお, $\mathrm{OC}$ から $\mathrm{FP}$ 一 のオピオイドスイッチングに要した日数の中央值は 8.5 日 (3 一54 日) であり, 観察項目に対する併用薬剤 (表 1)による影 響は認められなかった. また, オピオイドスイッチング前後で NSAIDs (非ステロイド性消炎鎮痛薬) やステロイドの増減し た症例はなかった。 


\section{考 察}

本試験の結果, $\mathrm{OC}$ の副作用発現例から FP 副作用出現早 期に切り替えることによって, NRS 值は改善傾向を示し, 便秘, 眠気のスコアは有意に改善した。

$\mathrm{NRS}$ 值の中央值は, $\mathrm{OC}$ 投与時 2.9 から FP 投与 10 日後また は中止時 1.6 一低下した. がん疼痛の薬物治療に関するガイド ラインでは, NRS 值が 1-3 の場合を軽度と便宜的に定めてい るが4), OC から FPへのオピオイドスイッチングにより NRS 值は軽度の範囲内に維持できていたことになる.

便秘については, 症状スコアの中央值が 1.4 から 0.3 に有意 に改善した.一般にオピオイド鎮痛薬による便秘の発現頻度は 非常に高く，しかも耐性を生じることなく投与期間中は継続す るとされる る。たがって, 便秘は嘔気・嘔吐, 食欲不振などの 消化器症状にも影響を与えるため, オピオイド鎮痛薬を継続使 用する際には, 便通を適切にコントロールすることが重要とな る. また, 一般に女性の便秘有訴率は男性よりも高く ${ }^{\text {) }}$, 日常の 生活に影響を与えることが想定されるため, 今回 FP 投与後に 便秘スコアや 1 日の排便回数が改善したことの意義は大きい と考えられる.さらに, OC 投与時には緩下剤 (マグネシウム製 剤など) を併用していたが, FP オピオイドスイッチング後は下 剂が不要となった例も認められ, 服用している薬剤数の低減に も寄与していた。

日中の眠気は, 家事を行っている女性にとっては ADLをさ またげる重要な因子となる可能性が高い. 終末期の眠気につい ては, 松尾らが不快な眠気に影響する因子を検討している7 . そ の中で, 女性, 60 歳未満の若年者, 入院から死亡までの期間が 7 日以上あること, 抑うつ状態の 3 つが独立した因子として影響 していた. 婦人科がん領域では, これら 3 つの因子があてはま ることが多いため, 今回, FPによって症状スコアが改善したこ との意義は大きい.

オピオイド鎮痛薬の眠気は投与開始初期や増量時出現する ことが多いが, 耐性がすみやかに生じ, 数日以内に自然に軽減, ないし消失することが多( ${ }^{8)}$ といわれている. しかし, 今回の 被験者の中に OC $10 \mathrm{mg}$ /日を 54 日間投与後に眠気の副作用に よって FPへ切り替えた症例が含まれていた. オキシコドン徐 放性製剂の国内臨床試験によると, 眠気の副作用は投与 1 週 後, 4 週後, 8 週後で,それぞれ $41.3 \%, 32.0 \%, 36.4 \%$ 発現してい $た^{9}$. 症例 2 は 54 日間の投与後に眠気に関する苦痛を訴えた症 例であったが, 他の症例と同様に副作用発現早期に改善が認め られた. 眠気はオピオイド鎮痛薬だけが原因ではなく, 患者の 病態変化や他の薬物などの原因を考慮する必要があるが, 必要 に応じてオピオイドスイッチイングを行う必要があることが 示唆された.

これまでの臨床研究においても, FP は同等の鎮痛効果を示 す用量ではモルヒネ経口薬やオキシコドン経口薬と比べて便 秘や眠気などの副作用が少ないことが示されている 研究によって, 婦人科がん領域の疼痛管理においても同様に
FP の有用性が示された.

婦人科がん領域においては, 緩和医療の早期導入などを含む 緩和医療に関する概念がまだまだ一般的ではなく,がん患者に 対する苦痛緩和の対応が不十分である可能性が予想される.

本研究結果を参考に, 今後さらに症例を積み重䄈ることに よって, 婦人科がん領域における疼痛管理のさらなる実践を啓 発していきたい.

\section{文 献}

1)「地域がん専門診療施設のソフト面の整備拡充に関する研 究」班. 全がん協部位別臨床病期別 5 年相対生存率 (19972000 年: 初回入院治療症例)[cited 2011 July 1] [http: //www. gunma-cc. jp/sarukihan/seizonritu/seizonritu. html]

2) 日本婦人科腫瘍学会 編. 卵巣がん治療ガイドライン, 2010 年版. 金原出版, 東京, 2010; 16-7.

3) Clark AJ, Ahmedzai SH, Allan LG, et al. Efficacy and safety of transdermal fentanyl and sustained-release oral morphine in patients with cancer and chronic non-cancer pain. Curr Med Res Opin 2004; 1419-28.

4) 日本緩和医療学会緩和医療ガイドライン作成委員会 編. が ん疼痛の薬物療法に関するガイドライン, 2010 年版. 金原 出版, 東京, 2010; 26-7.

5) 上掲書 4), 48-9.

6) 厚生労働省. 平成 10 年 国民生活基礎調查の概況一性・年 齢階級・症状別にみた有訴者率 (人口千対) [cited 2011 JUL 1] [http: //www1. mhlw. go.jp/toukei/h10-ktyosa/hyo3_8. html]

7) 松尾直樹, 余宮きのみ, 金石圭祐. 終末期における眠気一不 快な眠気に影響寸る因子の検討. 緩和医療学 2005; 7: 28993.

8) 上掲書 4), 50 .

9) 武田文和, 舘野政也, 小山靖夫, 他. S-8117 の癌患者の痛み に対するオープンラベル試験一オピオイドナイーブ患者 に対する有効性および安全性一第 III相臨床試験. 臨医薬 2005; 21: 315-33.

10) 鈴木 勉, 今井哲司, 成田 年. フェンタニルの薬理学的特 性. 鎮痛薬・オピオイドペプチド研究会 編. 鎮痛・オピオ イド研究最前線. エルゼピア・ジャパン, 東京, 2002; 12939.

11) 鍋島俊隆. オピオイド受容体のサブタイプとその特性. 緩 和医療学 2009; 11: 149-54.

12) Staats PS, Markowitz J, Schein J. Incidence of constipation associated with long-acting opioid therapy: a comparative study. South Med J 2004; 97: 129-34.

鈴木 直: 講演料等 (グラクソ・スミスクライン(株), 受託研究 費・寄付金等 $(\mathrm{MSD}$ (株)

その他該当なし 


\title{
Short Communications
}

\section{The study on opioid switching for the purpose of the quality of life improvement in the gynecologic cancer}

\author{
Nao Suzuki, Ayako Yoshida, Yuko Nakagawa, Miho Hatano, \\ Noriyuki Yokomichi, Shinji Hosonuma, Norihito Yoshioka, \\ Tatsuru Ohara, Akiko Tozawa and Kazushige Kiguchi
}

Department of Obstetrics and Gynecology, St. Marianna University School of Medicine

\begin{abstract}
Oxycodone controlled-release (CR) tablets are used as a first-line opioid analgesic for cancer pain. However, use of oxycodone $\mathrm{CR}$ tablets is associated with toxicities such as drowsiness and constipation, leading to deterioration of the quality of life (QOL), especially in patients with gynecologic cancer. In contrast, fentanyl has a superior toxicity profile while still showing a strong analgesic effect. Although fentanyl has been approved for switching from opioid, there have been no Japanese studies of patients with gynecologic cancer who were switched to transdermal fentanyl after experiencing toxicity during therapy with oxycodone CR. More importantly early introduction of palliative therapy for pain has not been adopted routinely in the management of gynecologic cancer. Thus, it appears that treatment for patients with gynecologic cancer remains unsatisfactory at present. We conducted research into improvement of the toxicity profile and pain control with the aim of improving QOL for patients with gynecologic cancer. We showed that pain, drowsiness, and constipation could be significantly improved in gynecologic cancer patients as a result of switching to transdermal fentanyl therapy at an early stage.
\end{abstract}

Palliat Care Res 2012; 7(2): 363-7

Key words: gynecologic cancer, cancer pain, transdermal fentanyl, opioid switching, drowsiness

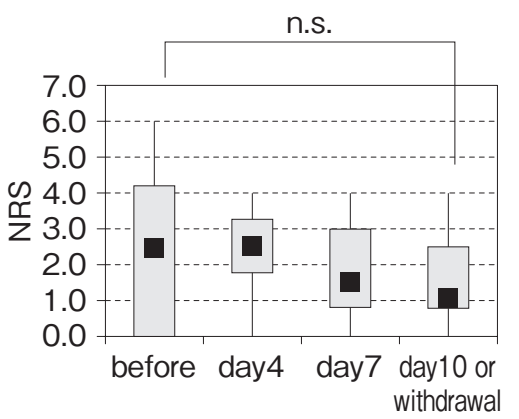

a. Pain Score

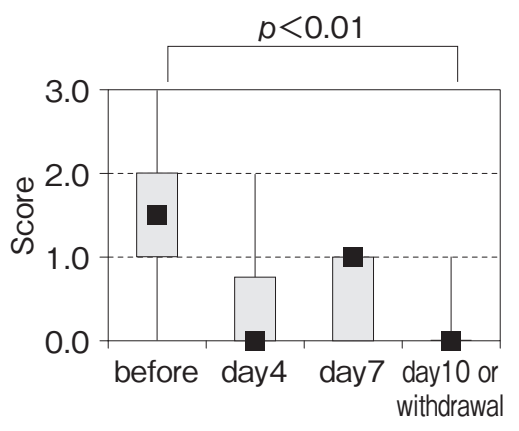

d. Constipation

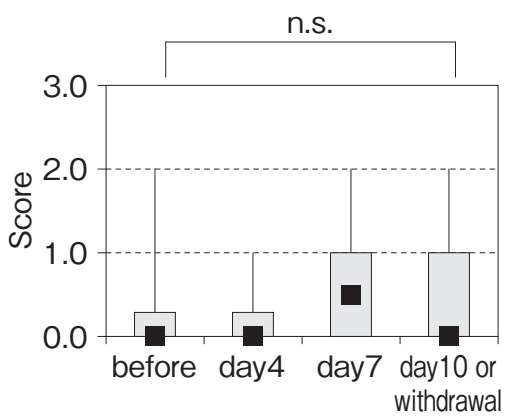

b. Nausea

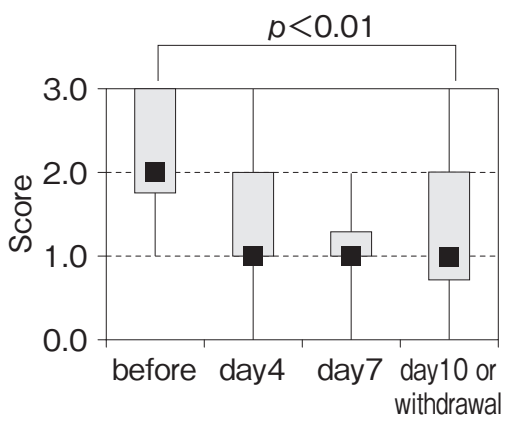

e. Drowsiness

Fig. 1 Case Score

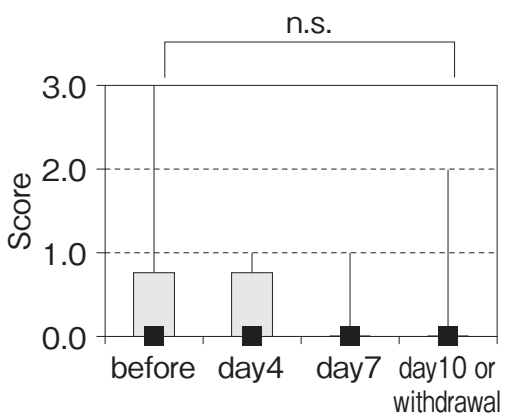

c. Vomitting 
Table 1 Profile of the subjects treated with TF $(n=10)$

\begin{tabular}{c|c|c|l|c|c|c|c|c}
\hline Pt. & $\begin{array}{c}\text { Age } \\
\text { (years) }\end{array}$ & $\begin{array}{c}\text { Disease } \\
\text { (cancer) }\end{array}$ & Metastasis part & $\begin{array}{c}\text { OC: a } \\
\text { periodically } \\
\text { dose } \\
\text { (mg/day) }\end{array}$ & $\begin{array}{c}\text { OC: a } \\
\text { dosage } \\
\text { period } \\
\text { (days) }\end{array}$ & $\begin{array}{c}\text { TF: a } \\
\text { first dose } \\
\text { (mg/3 days) }\end{array}$ & $\begin{array}{c}\text { TF: a } \\
\text { last dose } \\
\text { (mg/3 days) }\end{array}$ & $\begin{array}{c}\text { Concomitant } \\
\text { Painkiller }\end{array}$ \\
\hline 1 & 55 & corpus (pri) & $\begin{array}{l}\text { peritoneal dissemination, } \\
\text { digestive organs, } \\
\text { lymph node }\end{array}$ & 10 & 9 & 2.1 & 2.1 & none \\
\hline 2 & 46 & ovary (rec) & $\begin{array}{l}\text { peritoneal dissemination, } \\
\text { lung, spleen }\end{array}$ & 10 & 54 & 2.1 & 2.1 & NSAIDs \\
\hline 3 & 37 & ovary (rec) & lymph node & 10 & 10 & 2.1 & 2.1 & NSAIDs \\
\hline 4 & 51 & ovary (pri) & $\begin{array}{l}\text { peritoneal dissemination, } \\
\text { liver }\end{array}$ & 10 & 6 & 2.1 & 2.1 & NSAIDs \\
\hline 5 & 36 & cervix (pri) & bone & 10 & 3 & 2.1 & 2.1 & NSAIDs \\
\hline 6 & 51 & cervix (rec) & liver, bone & 10 & 14 & 2.1 & 2.1 & NSAIDs \\
\hline 7 & 55 & corpus (rec) & vagina, lymph node & 10 & 8 & 2.1 & 2.1 & NSAIDs \\
\hline 8 & 74 & corpus (rec) & vagina, lung & 10 & 9 & 2.1 & 2.1 & none \\
\hline 9 & 69 & corpus (rec) & lymph node, bone & 40 & 12 & 4.2 & 8.4 & NSAIDs \\
\hline 10 & 59 & cervix (rec) & lung & 10 & 5 & 2.1 & 4.2 & none \\
\hline
\end{tabular}

Pt.: patients, pri: primary, rec: recurrence, OC: oxicodon, TF: transdermal fentanyl 